\title{
Exploring the Metaphors of Loyalty, Courage and Friendship in Harry Potter Novels and their Turkish Translations
}

\author{
1, *Yaser Hadidi iD; ${ }^{2}$ Fatemeh Zare \\ University of Tabriz, Iran \\ *Corresponding author: hadidiy@ hotmail.com
}

\begin{abstract}
In studies on Conceptual Metaphor Theory and the Metaphor Master List scholars have come up with over the years, the metaphors (target domains) of loyalty, courage and friendship figure among very important ones. In this study, we undertake to explore these three metaphors in the Harry Potter series, as these three conceptual domains also happen to constitute three underlying themes in these novels. Cross-linguistic work in this regard is in its infancy and would benefit from ongoing research, because our knowledge of metaphors is only useful insofar as we can determine if a domain is universally and cross-linguistically also used to conceptualize a given target concept similarly in another language, or if it is found to be subject to some variation between the two languages being compared. We look at how these three generic-level concepts are conceptualized in English and their translations into Turkish, and if the cross-domain mappings are similar/different in the two languages, offering further insights into how far cognitive reality and its metaphorical realization differ between English and Turkish from a Cognitive Linguistics vantage point.
\end{abstract}

Keywords: metaphor, courage, loyalty, friendship, Harry Potter novels, English, Turkish.

\section{Introduction}

Metaphors are a fertile resource for research purposes because languages are interwoven with myriad types of them. Kövecses (2005) identifies culture as the foremost dimension of metaphor, which means that by exploring prominent and primary cognitive and social concepts like loyalty, courage and friendship as instances of metaphors, we can come closer to the core of culture and its linguistic manifestations. He also assumes that both culture and language are engaged with making meaning (Kövecses, 2010). 
In treating the applied linguistic implications and applications of conceptual metaphor theory, many like Boers (2000a, b), Cameron (2003) and Zanotto et al. (2008) have discussed the significance of expanding metaphorical awareness on intellectual and literacy levels. The fact is that conceptual metaphors make up an important part of human mind's meaning-making and cognitive capacity, which renders important such consciousness in terms of knowledge structures over and above mere ability in language.

For the purposes of Cognitive Linguistics, a simple definition of a conceptual metaphor is proposed as "understanding and experiencing one kind of thing in terms of another" (Lakoff \& Johnson, 2003: p.6). Another definition which defines metaphor in terms of two domains, namely source and target domain, is suggested by Kövecses (2010a, p. 4) who defines metaphor as "understanding one conceptual domain in terms of another conceptual domain". This shift of focus from thing to domain in the definition of metaphor is probably because the term domain, in addition to bearing the collection of concepts or entities, takes the background knowledge structures consisting of related concepts and inferences into consideration (Nabeshima, 2017: p.123). Conceptual metaphor theory takes metaphor as a conceptual tool for "structuring, restructuring and even creating reality" (Lakeoff \& Johnson, 1980). In this sense, metaphors will award a concrete nature to abstract and indefinite concepts such as loyalty, courage and friendship.

Probing metaphors within a culture and among different individuals has made it clear that most of the metaphors using specific domains are used in largely similar ways, at least intra-culturally (Kövecses, 2010). Kövecses (2005) demonstrates that there is a lot of inter-cultural universality too, even across cultures thought to be too different to allow it. He argues that this is the case especially when it comes to such rather universal sources of human language conceptualization as experiential bases and bodily experiences.

The interesting question is inter-cultural variation, the areas of conceptualization particular to individual cultures. Part of these, a large part as Kövecses shows in interesting detail, is again explainable by finding that the same universal metaphorical templates are being used, albeit in slightly different metaphorical mappings or entailments. But there is this intracultural dimension to each culture, albeit small, that conceptualizes abstract meaning metaphorically in a way only peculiar to the said culture. This is explained by the differential world experience, schematic construal, and social variables.

In addition, diachronic studies of metaphor have also been undertaken by different researchers like Mischler (2013) and Layegh et al (2020) within which the source 
and target domains of conceptual metaphors are investigated across time periods. In terms of cross-linguistic data, there is still a long way to go to conduct more synchronic studies of the conceptual metaphors across many understudied languages. Saghafiasl and Hadidi (2019), as once example, looked at a sample of popular animated English movies, in an attempt to see how the conceptual metaphors used and addressed to children were identical with those in the Turkish translation. As another, Naeimi and Hadidi (2019) explored some inter-cultural Adjustments in the Translation of Modern English Fiction into Turkish.

In this same spirit, the present study picks up on the same cross-linguistic strand towards further exploring Turkish as an understudied language with respect to English. What of course hasn't been specifically looked at is the conceptualization of the important metaphors of LOYALTY, COURAGE, and FRIENDSHIP, in Harry Potter and their translations into many languages. Recognizing these metaphors in the well-known and widely read Harry Potter novels and their rendering in other languages will be conducive to certain insights and responses in these issues of culture, cognition and language. There are a great deal of studies taking into account different languages by comparing metaphors. One comparison of this type can be between English and Turkish. We attempted to delve into a relatively unexplored section in translation of English metaphors of loyalty, courage and friendship into Turkish in Harry Potter novels.

In the study by Kövecses (2005), it is pointed out concerning the provenance of source domains that since the human body and the brain are predominantly universal, the metaphorical structures that are related to them will also be universal. It can explain why many conceptual metaphors can be found manifested along similar linguistic lines in a large number of unrelated languages. If we go beyond looking at metaphorically used linguistic expressions in different languages and, instead of linguistic metaphors, we look at conceptual metaphors, we begin to notice that many conceptual metaphors appear in a wide range of languages. (Kővecses, 2010).

This study undertakes a cross-linguistic analysis between the important and popular modern prose fiction series, Harry Potter, and their Turkish translation texts, to see if the same conceptual metaphors are used by both the writer and the translator to conceptualize the concepts of LOYALTY, FRIENDSHIP and COURAGE, and if the translator employs a metaphorical or literal language in order to convey the significance of these three concepts. 


\section{Methodology}

\section{Corpus}

This study tries to inspect metaphors within a qualitative scheme, which is a popular way of metaphor exploration. The materials of this exploration consist of famous English Harry Potter novel series: 1) Harry Potter and Philosopher's Stone (1997), 2) Harry Potter and Chamber of Secrets (1998), 3) Harry Potter and Prisoner of Azkaban (1999), 4) Harry Potter and Goblet of Fire (2000), 5) Harry Potter and Order of the Phoenics (2003), 6) Harry Potter and Half-Blood Prince (2005) and 7) Harry Potter and Deathly Hallows (2007) written by British author J. K. Rowling and their Turkish translations including 1) Harry Potter ve Felsefe Taşı ( 2001) by Üklü Tamer, 2) Harry Potter ve Surlar Odasi (2001) by Sevin Okyay, 3) Harry Potter ve Azkaban Tutsağ 1 (2001a), 4) Harry Potter ve Ateş Kadehı (2001b), 5) Harry Potter ve Zümrüdủanka Yoldaşliğı (2003), 6) Harry Potter ve Melez Prens (2005) and 7) Harry Potter ve Ölüm Yadigarları (2007) by Ktlukhan Kutlu and Sevin Okyay. All instances of LOYALTY, COURAGE, and FRIENDSHIP metaphors are identified.

\section{Model of Analysis}

In this study, the analysis is conducted within the framework of Conceptual Metaphor Theory, in general, and in particular, Kövecses's framework for metaphors (2005). Furthermore, metaphor identification procedure is carried out according to MIP (Metaphor Identification Procedure) (Pragglejaz Group, 2007), a reliable and explicit tool for marking metaphorically used words. Each instance of LOYALTY, COURAGE, and FRIENDSHIP metaphors is checked according to MIP throughout these materials to be put under the categories of either metaphorical or literal use of language. Afterwards, the metaphorical uses of them are analyzed according to Kövecses's framework to investigate its conceptualizing process and finally to compare it with its conceptualized counterpart in Turkish.

\section{Procedure of Analysis}

The text of the English novel together with its Turkish translation was inspected, with the purpose to recognize all potential loyalty, courage and friendship conceptual metaphors couched in a metaphorically used language.

Following MIP, we read the entire text of the novels to establish a general understanding of the meaning, followed by determining the lexical units of interest 
in the text. Then, for each lexical unit, its meaning in context as well as its core meaning was established. These two meanings were then compared to see whether they contrasted with each other. If the contextual meaning contrasted with the basic meaning, but could be understood in comparison with it, the lexical unit was marked as metaphorical. This same procedure was applied to the Turkish translation text as well.

The next step was to discover the source and target domains involved in the metaphorically marked linguistic data. In this stage, we tried to identify the domains of conceptual metaphors represented in the form of A IS B.

The last step in the analysis involved comparing and contrasting the conceptual metaphors taken from the source text with their counterparts in the target text.

\section{Results and Discussion}

The following table (table 1) contains examples of the same conceptual metaphor in both English and Turkish Harry Potter novels to conceptualize the concepts of loyalty, courage and friendship by both English writer and the Turkish translator.

\section{Table 1}

Examples of the same conceptual metaphors for loyalty, courage and friendship by both the English writer and the Turkish translator of Harry Potter novels

\begin{tabular}{|c|c|}
\hline English & Turkish \\
\hline \multicolumn{2}{|c|}{ 1. FRIENDSHIP IS A JOURNEY } \\
\hline $\begin{array}{l}\text {..."end of Ron and Hermione's } \\
\text { friendship" (Rowling, 1999. p. 130). }\end{array}$ & $\begin{array}{l}\text { "Ron'la Hermione'nin arkadaşlı̆̆ının sonu } \\
\text { gelmiş gibi görünüyordu" (Kutlu \& Okyay, } \\
\text { 2001a. p. 103). } \\
\text { Lit.: it seems like the end of Ron and } \\
\text { Hermione's friendship has come. }\end{array}$ \\
\hline \multicolumn{2}{|c|}{ 2. COURAGE IS A PHYSICAL PROPERTY } \\
\hline $\begin{array}{l}\text { "All that is needed is a little courage" } \\
\text { (Rowling, 2000. p. 8). }\end{array}$ & $\begin{array}{c}\text { "Gerekli olan tek şey, senin biraz daha } \\
\text { cesaret göstermen" (Kutlu \& Okyay, 2001b. p. 4). } \\
\text { Lit.: All that is needed is that you should } \\
\text { show a little courage. }\end{array}$ \\
\hline 3. COURAGE & A PHYSICAL PROPERTY \\
\hline
\end{tabular}




\begin{tabular}{|c|c|}
\hline $\begin{array}{l}\text { "He was too busy screwing up his } \\
\text { courage" (Rowling, 2000. p. 257). }\end{array}$ & $\begin{array}{l}\text {... "cesaretini toplamakla meşguldü" } \\
\text { (Kutlu \& Okyay, 2001b. p. 162). } \\
\text { Lit.: He was busy screwing up his } \\
\text { courage. }\end{array}$ \\
\hline \multicolumn{2}{|c|}{ 4. FRIENDSHIP IS A MACHINE } \\
\hline $\begin{array}{l}\text {..."to their recently repaired } \\
\text { friendship" (Rowling, 2000. p. 252). }\end{array}$ & $\begin{array}{l}\text { "Aralarının yeni düzelmiş olmasının } \\
\text { hatırına" (Kutlu \& Okyay, 2001b. p. 159). } \\
\text { Lit.: to give form to any of his emotions }\end{array}$ \\
\hline \multicolumn{2}{|c|}{ 5. FRIENDSHIP IS A HUMAN (OR PART OF A HUMAN BODY) } \\
\hline $\begin{array}{l}\text { "Extend them the hand of friendship" } \\
\text { (Rowling, 2000. p. 457). }\end{array}$ & $\begin{array}{l}\text { "Onlara hemen dostluk elini uzat" (Kutlu } \\
\text { \& Okyay, 2001b. p. 290). } \\
\text { Lit.: Extend them the hand of friendship }\end{array}$ \\
\hline \multicolumn{2}{|c|}{ 6. FRIENDSHIP IS A BOND } \\
\hline $\begin{array}{l}\text {.. "maintain links of friendship" } \\
\text { (Rowling, 2003. p. 125). }\end{array}$ & $\begin{array}{l}\text {..."dostluk bağlarımızı sürdürüyoruz" } \\
\text { (Kutlu \& Okyay, 2003. p. 101). } \\
\text { Lit.: maintain links of our friendship. }\end{array}$ \\
\hline \multicolumn{2}{|c|}{ 7. COURAGE IS PHYSICAL POWER } \\
\hline $\begin{array}{l}\text { "Your wand now contained the power } \\
\text { of your enormous courage and" ... (Rowling, } \\
\text { 2007. p. 375). }\end{array}$ & $\begin{array}{l}\text {... "asan şimdi senin muazzam cesaretini } \\
\text {... barindiriour" (Kutlu \& Okyay, 2007. p. 360). } \\
\text { Lit.: your wand now embraced your } \\
\text { enormous courage. }\end{array}$ \\
\hline \multicolumn{2}{|c|}{ 8. COURAGE IS PHYSICAL PROPERTY } \\
\hline $\begin{array}{l}\text {..."screwed up his courage" } \\
\text { (Rowling, 1997. 235). }\end{array}$ & $\begin{array}{c}\text {... "bütün cesaretini topladi" (Tamer, } \\
\text { 2001. p. 160). } \\
\text { Lit.: gathered all his courage. }\end{array}$ \\
\hline \multicolumn{2}{|c|}{ 9. COURAGE IS MOTION } \\
\hline $\begin{array}{l}\text {..."her courage returned now" } \\
\text { (Rowling, 2007. p. 352) }\end{array}$ & $\begin{array}{l}\text {... "cesareti geri gelmiş gibiydi" (Kutlu \& } \\
\text { Okyay, 2007. p. } 334 \text { ) } \\
\text { Lit.: her courage seems to return }\end{array}$ \\
\hline \multicolumn{2}{|c|}{ 10. COURAGE IS SPORT } \\
\hline $\begin{array}{l}\text { "Your courage won" (Rowling, } 2007 . \\
\text { p. 375). }\end{array}$ & $\begin{array}{l}\text {... "cesaretini kazandı" (Kutlu \& Okyay, } \\
\text { 2007. p. 360). } \\
\text { Lit.: Your courage won. }\end{array}$ \\
\hline \multicolumn{2}{|c|}{ 11. COURAGE IS PHYSICAL PROPERTY } \\
\hline $\begin{array}{l}\text { "Plenty of courage. I see" (Rowling, } \\
\text { 1997. p. 97). }\end{array}$ & $\begin{array}{l}\text {... "bayagi gőzüpek" (Tamer, 2001. p. } \\
\text { 65). } \\
\text { Lit.: pretty daring }\end{array}$ \\
\hline
\end{tabular}


On the other hand, in the following table (Table 2), there are instances of employing different conceptual metaphors to conceptualize the same abstract concept by the English writer and the Turkish translator of Harry Potter novels.

\section{Table 2}

Instances of different conceptual metaphors for friendship, courage and loyalty used by the English writer and the Turkish translator of Harry Potter novels

\begin{tabular}{|c|c|}
\hline English & Turkish \\
\hline $\begin{array}{c}\text { 1. COURAGE IS NATURAL } \\
\text { FORCE }\end{array}$ & $\begin{array}{l}\text { COURAGE IS A PHYSICAL } \\
\text { OBJECT (filling a container: human body as } \\
\text { container) }\end{array}$ \\
\hline $\begin{array}{l}\text {... "firing him with something that was } \\
\text { like courage" (Rowling, 2007. 44). }\end{array}$ & $\begin{array}{l}\text {... "içine cesaret diye adlandirilabilecek } \\
\text { bir şeyle doldurdu" (Kutlu \& Okyay, 2007. p. } \\
42 \text { ). } \\
\text { Lit.: filled with something that could be } \\
\text { called courage }\end{array}$ \\
\hline 2. LOYALTY IS A BUILDING & LOYALTY IS MOTION \\
\hline $\begin{array}{l}\text {... "somebody whose loyalty has never } \\
\text { wavered" (Rowling, 2000. p. 8). }\end{array}$ & $\begin{array}{l}\text {... "sadakati hiç sarsılmamış birine" } \\
\text { (Kutlu \& Okyay, 2001b. p. 4). } \\
\text { Lit.: to someone whose loyalty has } \\
\text { never been shaken. }\end{array}$ \\
\hline 3. LOYALTY IS A BUILDING & LOYALTY IS MOTION \\
\hline $\begin{array}{l}\text {... "may your loyalty never waver } \\
\text { again" (Rowling, 2000. p. 419). }\end{array}$ & $\begin{array}{l}\text {... "sadakatin bir daha hiç sarsılmasin" } \\
\text { (Kutlu \& Okyay, 2001b. p. 266). } \\
\text { Lit.: may your loyalty never sudder } \\
\text { again. }\end{array}$ \\
\hline 4. FRIENDSHIP IS A GAME & FRIENDSHIP IS A BUILDING \\
\hline $\begin{array}{l}\text { "How could such friendships fail?" } \\
\text { (Rowling, 2003. p. 122). }\end{array}$ & $\begin{array}{l}\text {... "böyle dostluklar çoker miydi?" } \\
\text { (Kutlu \& Okyay, 2003. p. 99). } \\
\text { Lit.: Do such friendships collapse? }\end{array}$ \\
\hline $\begin{array}{c}\text { 5. LOYALTY IS A PHYSICAL } \\
\text { OBJECT }\end{array}$ & $\begin{array}{l}\text { LOYALTY IS PROXIMITY (to } \\
\text { a person) }\end{array}$ \\
\hline
\end{tabular}




\begin{tabular}{|c|c|}
\hline $\begin{array}{c}\text {... "and he -Percy- knew where his } \\
\text { loyalty lay" (Rowling, 2003. p. 43). }\end{array}$ & $\begin{array}{c}\text {.. "ve o -Perce yani- kimin tarafinda } \\
\text { olmas1 gerektiğini biliyormuş" (Kutlu \& } \\
\text { Okyay, 2003. p. 37). }\end{array}$ \\
$\begin{array}{c}\text { Lit.: knew on whose side he should } \\
\text { stand }\end{array}$ \\
\hline 6. FRIENDSHIP IS A LIVING \\
ORGANISM
\end{tabular}$\quad \begin{gathered}\text { FRIENDSHIP IS A JOURNEY } \\
\text { "Could their friendship survive it?" } \\
\text { (Rowling, 2005. p. 150). }\end{gathered}$

According to the results, as shown in the tables, it turned out that in most of the cases, the same underlying conceptual metaphor was used by both the author and the translator for the three recurrent concepts in the novel: LOYALTY, COURAGE, and FRIENDSHIP. As can be seen, the frequency of similar conceptual metaphor usage across the two languages is almost twice that of variation introduced by the translator. As an example, FRIENDSHIP as an abstract target domain, is conceptualized as a JOURNEY, a concrete source domain, with an end/destination, by both the writer and the translator. The results are in line with common debate that there exists an experiential bases to metaphor provenance. Similar experiences, which are pertinent to human relationships such as friendship, and to moral concepts such as loyalty and courage, seem to take almost the same shapes across different languages, even among genetically and historically unrelated languages (Kovecses, 2000, 2005).

However, there are some cases in which the writer and the translator resorted to varying types of conceptual metaphor to conceptualize the intangible terms. Metaphorically used expressions and words may vary considerably across different languages (Kövecses, 2010). As an instance, in the English novel, the abstract concept of COURAGE was conceptualized as a natural force, namely FIRE, which may give rise to some events, while in the Turkish translation, the same concept is conceptualized using the concrete domain of a physical object which can fill a container, in this case, the human body. In this example, the target domain is conceptualized differently in the linguistic metaphor. These types of variation may occur as a result of cultural differences (Kövecses, 2005) involving a range of possibilities ranging from a certain conceptual domain not existing in the target language, or not being a conventional one in a language, or used just as an attempt to deepen and make the text interesting for a special culture by adding variety to it using a personalized style. 
As a response to the second research question, it was revealed that the translator rarely drew upon literal language to render a metaphorical concept. This is an important finding: literary translators tend most of the time to render a conceptual metaphor in a target metaphorical form, albeit a different one, as in the case of the current translator, rather than making use of literal language.

To conclude, one can argue that both English and Turkish speakers have the same or nearly the same conceptualizations available in their cognitive templates at least, for the concepts of loyalty, courage and friendship, which could be explained by a universal (bodily, physiological) experiential basis underlying most human cultures and societies.

The differences detected seem to be the product of two factors:

1) First of all, the translators may want to add their personalized taste to the translation, or they may take an advantage of different conceptualizations to make it more suited to the special social context.

2) Second, the metaphorical conceptual domain may exist in the target language, but there may not be the proper metaphorical/linguistic means to convey it in an actual linguistic metaphor.

As such, this study is in line with Kövecses who claims that it is convenient to set up two large groups of causes for metaphorical variations across languages: differential cognitive preferences and differential experiences. Differential experience involves differences in social- and cultural-contexts, in social and personal history, and in what we can term social and personal concern or interest (Kövecses 2005). Differences in the metaphor uses in particular cultures may derive from social and personal history as reported in Kövecses (2005). The findings are in general agreement with Ozcaliskan (2003), Saghafiasl \& Hadidi (2019) and Naeimi \& Hadidi (2019) whose findings, comparing English metaphors and their Turkish translations, show that conceptual metaphors are mostly universal and that there are similarities, more universality than variation, between the source and target domains of the linguistic metaphors in diverse languages and cultures when expressing similar meanings in similar contexts.

But as indicated above, all this is limited and will not have done justice to the dearth of our cross-linguistic insight; further comparative research can and should be undertaken in this field probing different languages, pointing to probably other interesting findings and preferences in languages. This would raise our knowledge of cultural and intercultural relationships, to suggest more source domains than what has been proposed and to explore other target domains. For one thing, and like many 
other languages with respect to English, cross-linguistic research between Turkish and English using cognitive linguistics means is also still in its infancy.

\section{Conclusion}

According to the above findings and discussion, this study falls in line with Kövecses's various arguments in his research. This supports the argument that it is convenient to set up two large groups of causes for metaphorical variations across languages: differential cognitive preferences and differential experiences. Differential experience involves differences in social- and cultural-contexts, in social and personal history, and in what we can term social and personal concern or interest (Kövecses 2005). Differences in the metaphor uses in particular cultures may derive from social and personal history as reported in Kövecses (2005). The findings are in general agreement with Ozcaliskan (2003), Saghafiasl \& Hadidi (2019) and Naeimi \& Hadidi (2019) whose findings, comparing English metaphors and their Turkish translations, show that conceptual metaphors are mostly universal and that there are similarities, more universality than variation, between the source and target domains of the linguistic metaphors in diverse languages and cultures when expressing similar meanings in similar contexts.

But as indicated above, all this is limited and will not have done justice to the dearth of our cross-linguistic insight; further comparative research can and should be undertaken in this field probing different languages, pointing to probably other interesting findings and preferences in languages. This would raise our knowledge of cultural and intercultural relationships, to suggest more source domains than what has been proposed and to explore other target domains. For one thing, and like many other languages with respect to English, cross-linguistic research between Turkish and English using cognitive linguistics means is also still in its infancy. This will also be subject to macro-cultural and micro-contextual influences, and consequently to various procedural strategies that shape the schematic structure of variable cognitive models of reality in the cultures compared (Salahshour, 2017). In an equally relevant vein, there will also be many links to literacy practices lying in such Cognitive Linguistics revolution of metaphor outlook, for instance the way in which cognitive, affective and linguistic domains affect strategy use and effective reading performance of foreign language learners (Talebi and Seifallahpur, 2015). 


\section{References}

Boers, F. (2000a). Enhancing metaphoric awareness in specialized reading. English for Specific Purposes, 19(2), 137-147

Boers, F. (2000b). Metaphor awareness and vocabulary retention. Applied Linguistics, 21(4), 553-571

Cameron, L. (2003). Metaphor in educational discourse. London: Continuum

Group, P. (2007). MIP: A method for identifying metaphorically used words in discourse. Metaphor and Symbol, 22(1), 1-39

Kövecses, Z. (2000). Metaphor and emotion: Language, culture, and body in human feeling. Cambridge. Cambridge: Cambridge University Press.

Kövecses, Z. (2005). Metaphor in culture: Universality and variation. Cambridge: Cambridge University Press.

Kövecses, Z. (2010). Metaphor, language and culture. DELTA vol.26 no.spe São Paula

Kövecses, Z. (2015). Where metaphors come from: Reconsidering context in metaphor. USA: Oxford University Press.

Kutlukhan, K. \& Okyay, S. (2001a). Harry Potter ve Azkaban tutsağı. Istanbul, Turkey: YKY

Kutlukhan, K. \& Okyay, S. (2001b). Harry Potter ve Ateş Kadehı. Istanbul, Turkey: YKY

Kutlukhan, K. \& Okyay, S. (2003). Harry Potter ve zümrüdüanka yoldaşliğı. Istanbul, Turkey: YKY

Kutlukhan, K. \& Okyay, S. (2005). Harry Potter ve melez prens. Istanbul, Turkey: YKY

Kutlukhan, K. \& Okyay, S. (2007). Harry Potter ve ölüm yadigarlarl. Istanbul, Turkey: YKY

Lakoff, G., \& Johnson, M. (1980). Metaphors we live by. Chicago: University of Chicago Press.

Lakoff, G., \& Johnson, M. (2003). Metaphors we live by. Chicago: University of Chicago Press.

Layegh, N., Hadidi, Y., Zohrabi, M. (2020). Revisiting Common Source and Target Domains in Conceptual Metaphors in a Sample of English Fiction: Implications for Literacy Practices and Advanced EFL Pedagogy. International Journal of Education \& Literacy Studies, 8(3), 116-128. ISSN: 2202-9478

Mischler, J. (2013). Metaphor across time and conceptual space. Amsterdam \& Philadelphia: John Benjamins.

Nabeshima, K. J. (2017). Domains in cognitive metaphor theory and metaphor processing. International Journal of Computational Linguistics Research, 8(3), 123-131.

Naeimi, P. \& Hadidi, Y. (2019). Inter-cultural Adjustments in the Translation of Modern English Fiction into Turkish. Proceedings of the $17^{\text {th }}$ international TELLSI conference, Tabriz, Iran, 2019. Tabriz: TELLSI

Okyay, S. (2001). Harry Potter ve sirlar odası. Istanbul, Turkey: YKY

O.. zcaliskan, Seyda. (2003). Metaphorical motion in crosslinguistic perspective: Acomparison of English and Turkish. Metaphor and Symbol, 18(3), 189-228.

Rowling, J. K. (1997). Harry Potter and the philosopher's stone. London. UK: Bloomsbury Rowling, J. K. (1998). Harry Potter and the chamber of secrets. London, UK: Bloomsbury Rowling, J. K. (1999). Harry Potter and the prisoner of Azkaban. London, UK: Bloomsbury Rowling, J. K. (2000). Harry Potter and the goblet of fire. London, UK: Bloomsbury Rowling, J. K. (2003). Harry Potter and the order of the Phoenix. London, UK: Bloomsbury Rowling, J. K. (2005). Harry Potter and the half-blood prince. London, UK: Bloomsbury Rowling, J. K. (2007). Harry Potter and the deathly hallows. London, UK: Bloomsbury 
Saghafiasl, A. \& Hadidi, Y. (2019). Cognitive Universality in Translating Animated English Movies into Turkish. Proceedings of the $17^{\text {th }}$ international TELLSI conference, Tabriz, Iran, 2019. Tabriz: TELLSI

Salahshour, F. (2017). A 'Thick Description' Genre Analysis of Death Announcement Notices. Khazar Journal of Humanities and Social Sciences. 20 (3), 63-76. DOI: 10.5782/2223-2621.2017.20.3.63

Talebi, S. H. \& Seifallahpur, B. (2015). Contributions of the cognitive, affective and linguistic domains to strategy use and degree of strategy use to effective reading performance. Khazar Journal of Humanities and Social Sciences. 18 (4), 17-34. DOI: 10.5782/2223-2621.2015.18.4.17

Tamer, Ü. (2001). Harry Potter ve felsefe taşı. Istanbul, Turkey: YKY

Zanotto, M. S., Cameron, L., \& Cavalcanti, M. C. (Eds.). (2008). Confronting metaphor in use: An applied linguistic approach (Vol. 173). Amsterdam \& Philadelphia: John Benjamins Publishing. 